\title{
The Cave of Fouvent, also called Abri Cuvier (Fouvent-le-Bas, Haute-Saône, France): Taphonomical analysis of a Late Pleistocene Hyena Den (OIS3)
}

La grotte de Fouvent, dit l'Abri Cuvier (Fouvent-le-Bas, Haute-Saône, France): analyse taphonomique d'un repaire d'hyènes du Pléistocène supérieur (OIS 3)

Jean-Baptiste Fourvel, Philippe Fosse, Philippe Fernandez and PierreOlivier Antoine

\section{(2) OpenEdition}

\section{Journals}

Electronic version

URL: http://journals.openedition.org/paleo/3010

DOI: 10.4000/paleo.3010

ISSN: $2101-0420$

\section{Publisher}

SAMRA

Printed version

Date of publication: 28 December 2014

Number of pages: $79-99$

ISSN: $1145-3370$

\section{Electronic reference}

Jean-Baptiste Fourvel, Philippe Fosse, Philippe Fernandez and Pierre-Olivier Antoine, « The Cave of Fouvent, also called Abri Cuvier (Fouvent-le-Bas, Haute-Saône, France): Taphonomical analysis of a Late Pleistocene Hyena Den (OIS3)», PALEO [Online], 25 | 2014, Online since 01 June 2016, connection on 07 July 2020. URL : http://journals.openedition.org/paleo/3010; DOl : https://doi.org/10.4000/ paleo.3010

This text was automatically generated on 7 July 2020.

PALEO est mis à disposition selon les termes de la licence Creative Commons Attribution - Pas d'Utilisation Commerciale - Pas de Modification 4.0 International. 


\title{
The Cave of Fouvent, also called
} Abri Cuvier (Fouvent-le-Bas, HauteSaône, France): Taphonomical analysis of a Late Pleistocene Hyena Den (OIS3)

\author{
La grotte de Fouvent, dit l'Abri Cuvier (Fouvent-le-Bas, Haute-Saône, France) : \\ analyse taphonomique d'un repaire d'hyènes du Pléistocène supérieur (OIS 3) \\ Jean-Baptiste Fourvel, Philippe Fosse, Philippe Fernandez and Pierre- \\ Olivier Antoine
}

The authors wish to thankJ. Detrey and all his team for the fieldwork carried out during the early 1990s. We thank the Dijon Muséum d'Histoire Naturelle and all the team there for facilitating access to collections and for lending us the bone material from the 1842 collection from Fouvent. This work is part of a PhD (JBF). We also wish to extend warm thanks to M. J.-P. Brugal, DR CNRS, without whom this work would not have been possible. Finally, we thank $F$. Delpech and C. Daujeard for their constructive comments.

\section{1 - Introduction}

1 Cavities provide shelter and are thus attractive sites for most human and animal groups. All predatory species (including the canidae, felidae, hyenidae, ursidae, mustelidae or viverridae families) use caves or rock shelters, either episodically or for longer occupations, and leave traces of their presence (bone remains, ichnology, coprolites, tooth marks). Predators play a recurrent role in the formation or modification of bone stocks. Palaeolithic human and carnivore groups share a common ecological base (habitat, food supply) and interacted frequently, as shown by work carried out over the past two centuries (Cartailhac 1881; Philippe and Fosse 2003; 
Daujeard 2008). The cave hyena is particularly recurrent in sites containing industries with faunal remains. The role of this carnivore in the formation (den) or the modification of accumulations has been widely debated (for a review, Fosse 1995).

The description of the Kirkdale bone accumulation (England) by Buckland (1822) provides the earliest definition of a cave hyena den characterized by the diversity and abundance of carnivores (in particular, the hyena), dominant juvenile and old ungulates, abundant gnawed bones and coprolites. In France, during the same period, extensive paleontological research (Cuvier 1825; Gervais 1870) and multiple descriptions (Thirria 1828, 1833; Nodot 1858-1859) were carried out at the site of Fouvent-le-Bas. New field operations were undertaken between the end of the 1980s and the beginning of the 1990s (Detrey 1992; Fourvel 2012).

3 There is no longer any doubt as to the taphonomic role of the hyena in the modern (e.g. Brain 1981) and fossil record (e.g. Fosse 1994). However, the behavioural variability of predators is evidenced among specific groups as well as between species with a priori distinctive bone-chewing capacities (Fourvel 2010; Fourvel \& Mwebi 2011; Fosse et al. 2011). The production of new taphonomic research is now required to categorize acquisition modes and accumulation processes. The study of fossil hyena dens remains a fundamental step in recognizing the role and the status of different (human and nonhuman) predators in archaeological and paleontological assemblages.

Consequently, this taphonomic analysis of the Fouvent site, formed during isotopic stage 3, contributes to defining the palaeoecological variations of the hyena and the identification of the taphonomic signature of this carnivore.

\section{2 - General site presentation}

\section{1 - Geographic location and geological setting}

5 The site known as Abri Cuvier is located at the extreme northwest of the Haute-Saône department (70), in Fouvent-le-Bas village (Fouvent-Saint-Andoche townland), near the Vannon River, at an altitude of about 200 metres (fig. 1). The site is in a karstic region and corresponds to an open fissure in Bathonian limestone (Detrey 1992). The cave no longer exists today as the limestone blocks were used for the foundations of a house. Nonetheless, the site was described in early publications at the time of discovery. These descriptions refer to a moderate-sized cavity: the cave was about ten metres long and four metres wide, with a height of nearly two metres. It had two entrances; the first of one by one metre and the second of one metre by $0.5 \mathrm{~m}$ (Nodot 1858-1859). Renewed work at the site in the 1980 s brought to light a shaft belonging to the original site (Detrey 1992; Fosse 1997; fig. 2).

\section{2 - History of research}

The history of paleontological research at Fouvent site spans the past two centuries. It underlines the evolution of research approaches to field observations and site context and the resulting interpretations (Fosse 1995).

7 The importance of the site for Quaternary paleontological research was revealed as soon as work began there, on account of the osteological distinction between modern 
and fossil hyena (Cuvier 1825) and the fact that the first mention of the fossil wolverine in France occurs there (Gervais 1870). It plays an essential role in the definition of the Pleistocene carnivore den (Nodot 1858-1859). The very first mention of Fouvent site was made by Cuvier (1812), whereas the first physical and geological description of the site was formulated by Édouard Thirria $(1828,1833)$, a mining engineer in Vesoul. He put forward the first hypothesis for the formation of the deposit; :"[...] it is very likely that the animal remains come from animals that died during the major Diluvian catastrophe, and that their bones were transported to the cave by the resulting flooding". Nodot (1858-1859), a member of the Académie Impériale des Sciences, Arts et Belles-Lettres de Dijon, published the first plan of the site (fig. 3). He put forward different arguments in favour of bone accumulation by the cave hyena (morphology of bone fractures, tooth marks). However, he explained that he could not observe the presence of coprolites, considered to be an incontestable sign of the use of the cave by these carnivores. Bouillerot (1881) published the first overview of the Fouvent site, along with the results of his own research.

Figure 1 - Location of Fouvent paleontological site. Map drawn up with Géoatlas $₫$ and Géoportail.

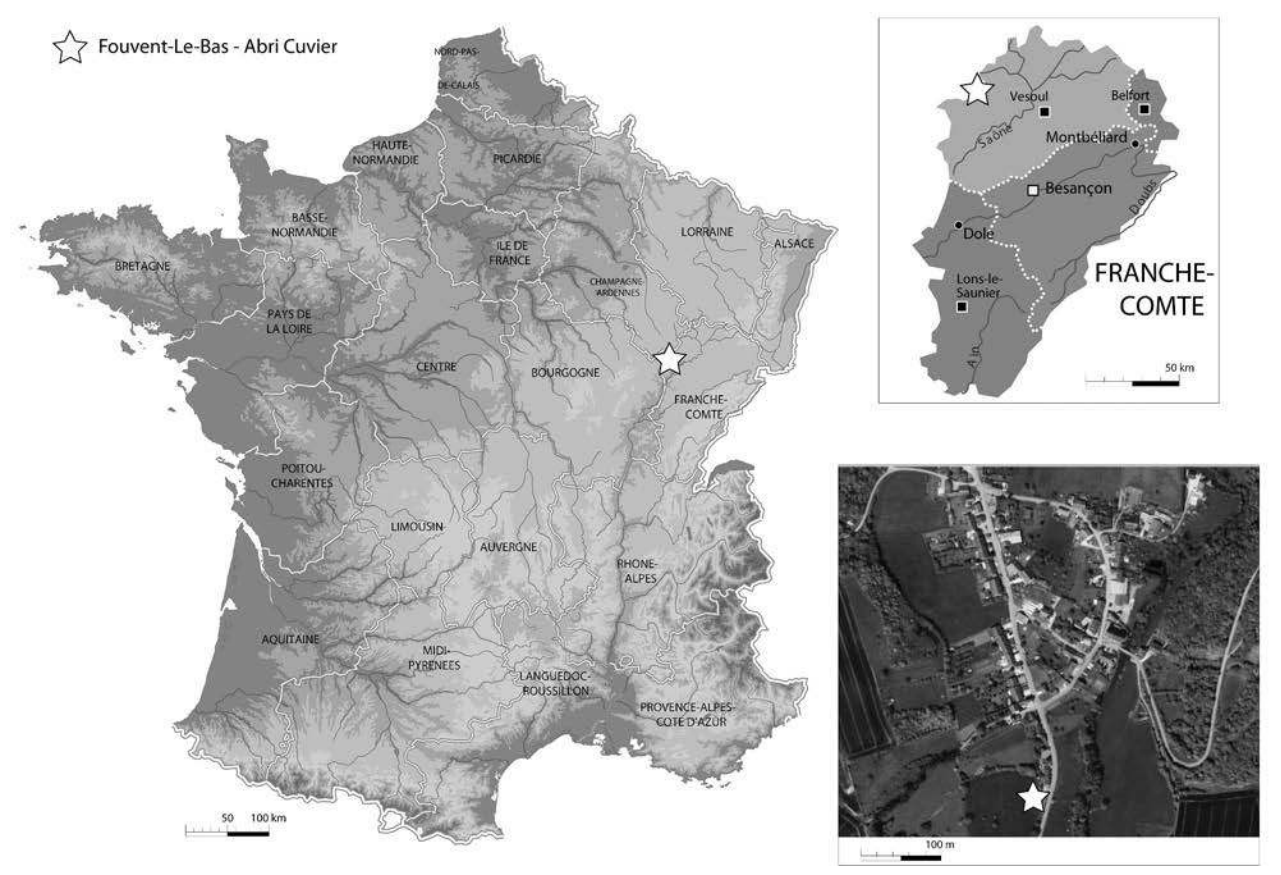


Figure 2 - Map of Fouvent paleontological site showing the different excavated areas (modified from Detrey 1992). Squares containing faunal remains are represented in grey.

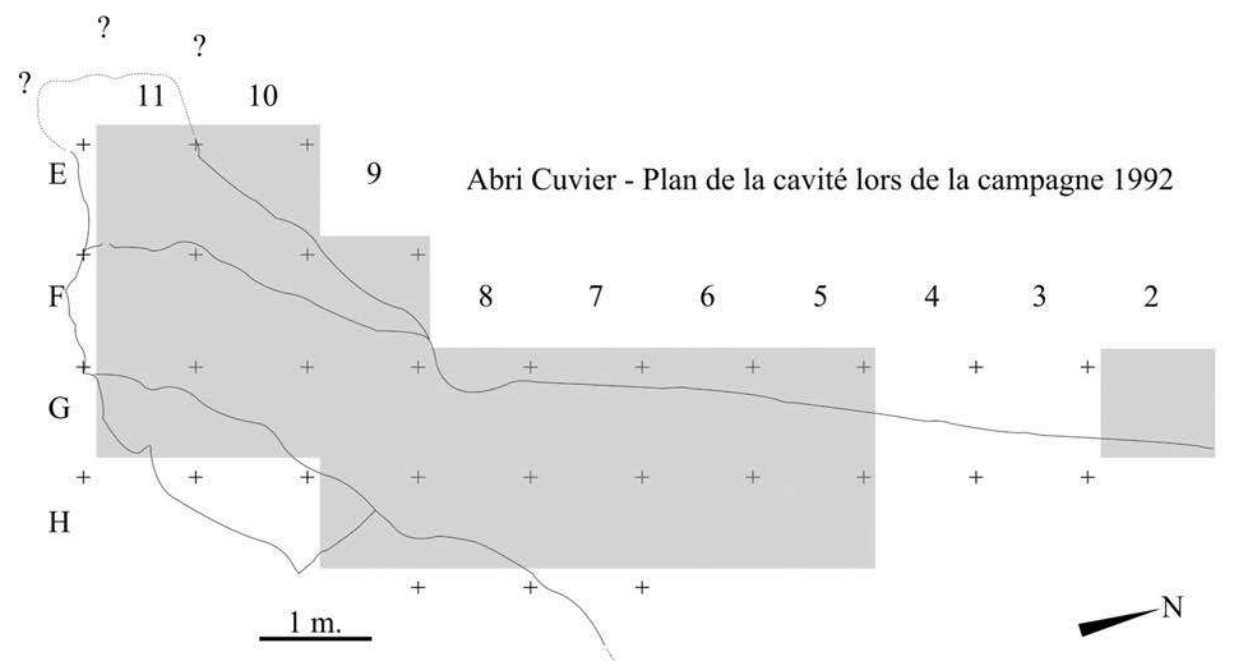

Figure 3 - Map of Fouvent during the 19th century (from Nodot 1858).

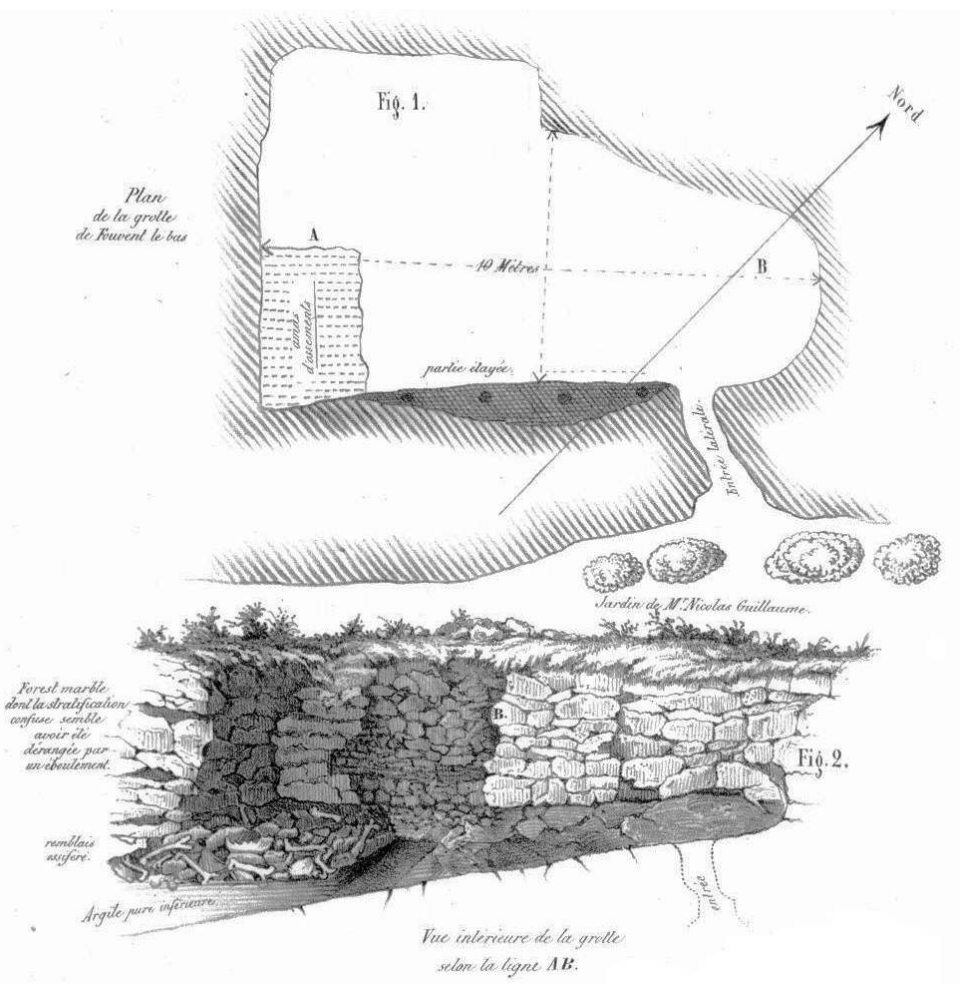

In comparison with observations on Kirkdale Cave (Buckland 1822), he deduced that Fouvent was undoubtedly a hyena den. This analysis represented the last work on the site until it was rediscovered during the second half of the $20^{\text {th }}$ century.

In 1989, renewed fieldwork was spurred on by the discovery of a shaft, about ten metres long and three metres wide, after the development of part of the property on which the site is located. This part, known as Abri Cuvier, underwent systematic excavation by J. Detrey, between 1989 and 1992 (Detrey 1992; Fosse 1997). For the time being, only a small part of the former cavity has been excavated and studied. 


\section{3 - Statigraphic context of the J. Detrey excavations (1989-1992)} $\mathrm{m}^{2}$. Abundant faunal remains were unearthed, in association with a small lithic assemblage made up of nearly 300 pieces (cores, tools, flakes) ascribed to a Châtelperronian or Mousterian facies (Fosse 1997). Detailed observation of the sediment led to the identification of four stratigraphic levels with preserved paleontological material (after Morin in Detrey 1992; fig. 4). The complex containing the upper levels (E) is characterized by silty-clayey levels topping coarser, underlying levels. The sedimentologic analysis revealed formation by runoff or colluviums (on account of sparse plant cover). Levels A and B are mostly made up of stones and cryoclastic gravel. The different calibres of cryoclastic gravel and the relatively abundant presence of matrix and collapsed blocks were used to subdivide complex B into two levels; B1 and B2. Complex C corresponds to a silty-clayey horizon interstratified with cryoclastic angular gravel with fine elements. Most of the sequence points to "relatively rigorous climatic conditions corresponding to a homogeneous infilling of detrital material derived from the surrounding karstic rock" (Morin in Detrey 1992 - p. 6). The identification of silty levels alternating with the cryoclastic levels (resulting from gelifraction) indicates phases of climatic amelioration (increase in temperature and humidity). The sedimentologic and stratigraphic analysis associated with the paleontological study (Lovis 1968; evolutionary gradient of horses in Fernandez, Guadelli, Fosse 2006) and the chronocultural attribution of the lithic material argue in favour of the formation of the assemblage during the course of isotopic stage 3.

\section{3 - Material and method}

\section{1 - Methodology}

11 The methods used here are from the fields of archaeology and carnivore taphonomy (sensu Brain 1981). Three main quantifications units were used: the Number of Remains (NR), either total (NRT), or determined (NRD), the Minimum Number of Elements (MNE) and the Minimum Number of Individuals (MNI). The characterization of hyena age structure is based on diverse works (Kruuk 1972; Mills 1982; Stiner 1994; Brugal, Fosse, Guadelli 1997). Based on these different methods, we retained five stages of tooth eruption/wear, applicable both to current and fossil populations (Fourvel 2012; tab. 1).

Many authors have developed models to characterize prey mortality and interpret ungulate acquisition strategies by human groups (e.g. Klein and Cruz-Uribe 1983; Stiner 1990; Steele 2005). Three theoretical mortality curves have been identified: i) the "catastrophic" profile (predominance of young and progressive diminution of adult and old individuals); ii) the "attritional" profile (natural mortality profile with a predominance of young and old individuals); iii) the "adult-dominant" profile" (showing the anthropogenic influence on predation according to Stiner 1990). The number of ungulates at Fouvent (and the quantity of remains for each taxon) does not enable us to establish curves for each species. The use of ternary distribution (three age classes: juvenile, adult, old sensu Stiner 1990) enables us de facto to increase the number 
of pieces and facilitates the comparison of the different mortality profiles. The application of ternary modelling is more difficult with hyenas, in particular for stage 2 individuals; which can be ascribed to either the juvenile or adult class. Young animals are reared by females until the age of 30 months (Kruuk 1972), or during the course of stage 2, from 1 to 4 years. In addition, the use of classes for ungulate size appeared to be necessary. Four sets were defined, taking into account taxa size and average body mass: small ungulates (roe deer), medium-sized ungulates (reindeer, red deer), large ungulates (megaloceros, horse, large bovids) and megaherbivores (mammoth, rhinoceros).

Figure 4 - Fouvent stratigraphic sequence (modified from Detrey 1992).

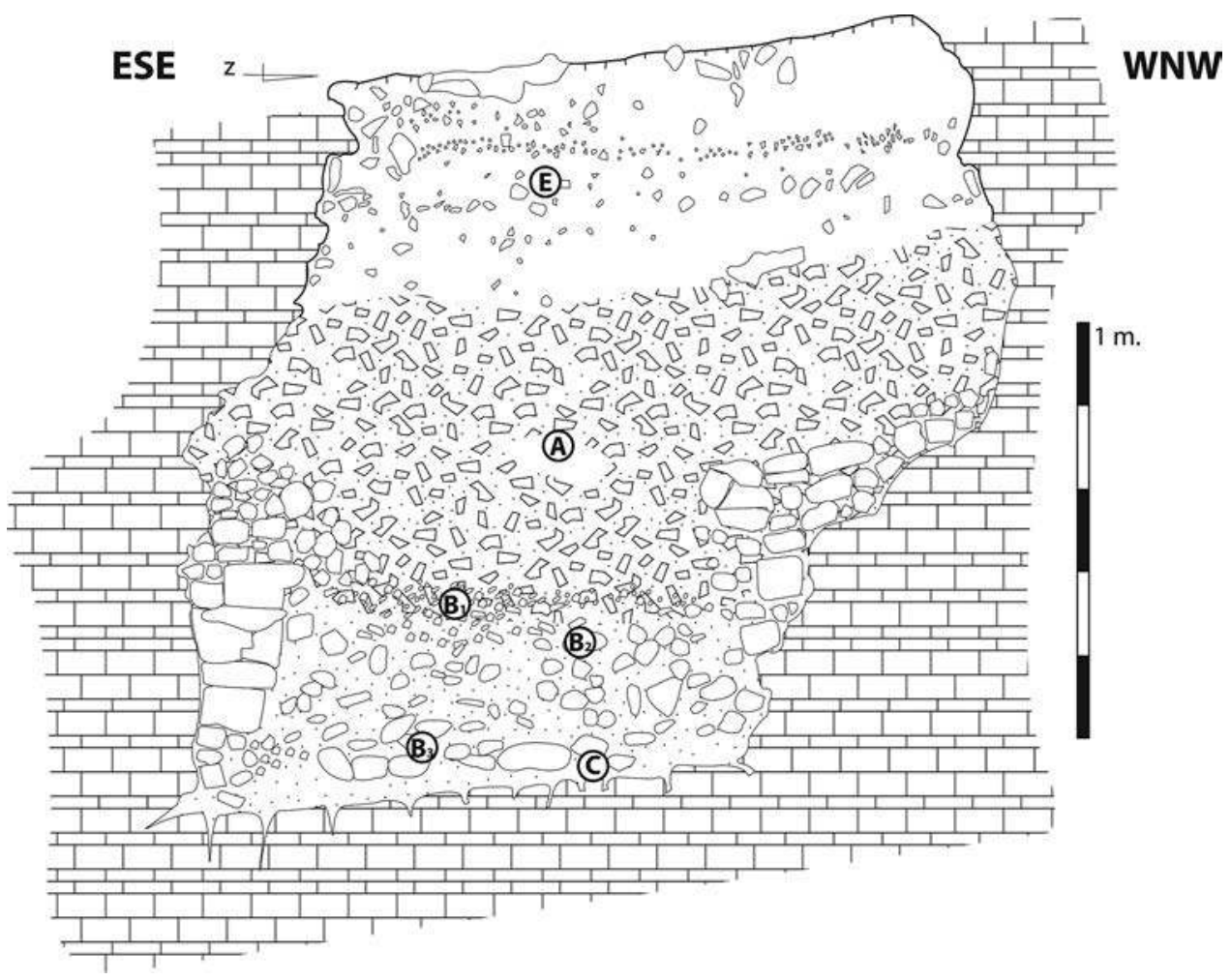

Table 1 - Description of tooth eruption and wear stages in hyenas.

\begin{tabular}{|l|l|l|}
\hline Stade & Description & Estimation \\
\hline Stade 1 & $\begin{array}{l}\text { De l'éruption, usure et chute des dents de lait jusqu'à l'éruption de l'ensemble des } \\
\text { jugales définitives }\end{array}$ & $0-12$ mois \\
\hline Stade 2 & $\begin{array}{l}\text { Mise en place et entrée en fonction de l'ensemble des dents permanentes (incisives, } \\
\text { canines et jugales) }\end{array}$ & $1-4$ ans \\
\hline Stade 3 & Usure partielle des dents & $4-6$ ans \\
\hline Stade 4 & Usure importante des jugales & $6-10$ ans \\
\hline Stade 5 & Usure complète des couronnes & $10-15$ ans \\
\hline
\end{tabular}

Based on the works of Stiner (1991), we divided ungulate skeletons into three main anatomic categories: elements of the axial, appendicular and cranial skeleton. This subdivision is part of the general sequence of carcass consumption by predators in three main stages: i) the consumption of ventral and abdominal parts, ii) then of the fleshy limb parts, iii) followed by consumption of the head (Kruuk 1972). We then subdivided each of these stages into anatomic (skeletal) sub-categories, based on more detailed data, such as damage and marks (sensu Brain 1981; Binford 1981) or reduction 
rates (sensu Richardson 1980; Bunn 1983). Long bone fragmentation is analyzed in detail, as it is used to characterize dens (e.g. Cruz-Uribe 1991; Fosse 1994; Pickering 2002). We use the method established by H. T. Bunn (1983): observation of long bone length and circumference proportions $(<1 / 2,>1 / 2$ and whole), with and without their extremities. The observation of bone breakage shape and the aspect and angle of the edge enables us to differentiate green bone breaks from those broken at a later stage (Villa and Mahieu 1991), and thus determine their inclusion (green bone fractures) or exclusion (dry or recent breaks) in our analysis. Our study aims to describe and characterize the diversity of marks observed on bone material, based on the pioneering studies in this domain (Sutcliffe 1970; Maguire, Pemberton, Collet 1980; Brain 1981; Binford 1981). Overall, these typologies include four types of marks, taking the general morphology of traces into account, for eight different alterations: i) (sub) circular marks (punctures and pits); ii) fracture marks (chipping-back and fracture scars) and bone reduction (scooping out and crenulated edges); iii) (elongated) friction marks (scoring and furrowing); iv) ingestion marks (for a precise definition or each alteration see Fourvel 2012). Three hundred and eighty-six remains (including 271 NRD and 115 nondetermined elements) have been excluded from the analysis of carnivore marks as they are too altered by abiotic elements (e.g. dissolution, concretions, disintegration), thereby rendering bone surfaces indecipherable.

\section{2 - Studied material}

14 Our study includes both of the osteological collections unearthed at Fouvent: the 1842 collection from the Dubois excavations, presented by Nodot (1858-1859) and revised by Lovis (1968), and the material from recent excavations 1989-1992 (dir. Detrey). A total of 14977 bone remains were analyzed (determined and non-determined), from the two series: 145 for the 1842 collection and 14832 for the recent material. The determined material ( $N R D=3347$ ) was attributed to 27 taxa, genera or families (depending on the taxonomic level), including 11 generic or specific (or even sub specific) attributions for carnivores and eight for ungulates (tab. 2).

\section{4 - Results}

\section{1 - Faunal list}

The material from 1842 was reexamined in order to review the taxonomic attributions and the faunal list, although some of the pieces are now missing (the mammoth teeth and the lion's mandible illustrated in the work of Lovis 1968). The cave bear U. spelaeus is the only identified bear species, whereas the brown bear Ursus arctos and the cave bear had been identified earlier. Other taxa present in this series had not been mentioned in earlier studies; a small canid (related to the red fox), evidenced by four pieces, and a lagomorph (NRT=1). Note also the presence of the wolverine G. gulo (NRT=1) and the reindeer $R$. tarandus (NRT=5). The material discovered between 1989 and 1992 is more abundant and diversified. The faunal lists for each level all have a common denominator: the systematic and abundant presence of the cave hyena $C$. $c$. spelaea. Among the 3347 determined remains, the best represented taxa are, by order of importance: the horse E. germanicus (27.3\% NRD, 16.8\%MNI), the hyena C. c. spelaea (25.4 \%NRD, 30.8 \%MNI), the large Bovinae Bos/Bison (7.2 \%NRD, $7.5 \% \mathrm{MNI}$ ), the woolly 
rhinoceros $C$. antiquitatis (6.7 \%NR, 9.9 \%MNI), the mammoth M. primigenius (6.6 \%NRD, 2 $\% \mathrm{MNI}$ ) and the reindeer $R$. tarandus (3.4\% NRD, $4.1 \% \mathrm{MNI})$.

Table 2 - Fouvent faunal list (NISP, MNI, MNE and related frequencies) per level.

\begin{tabular}{|c|c|c|c|c|c|c|c|c|c|c|c|c|c|c|c|c|c|c|c|c|c|c|c|}
\hline & 184 & & niv & & niv $E$ & & niv & & niv $A$ & & niv & & niv $\mathrm{E}$ & & niv & & $\mathrm{HS}$ & & & & ut nivea & & \\
\hline Taxon & $Z_{0}$ & \begin{tabular}{|l|l|}
$\mathbf{z}$ \\
$\mathbf{z}$
\end{tabular} & $Z_{D}$ & |z & $z_{D}$ & \begin{tabular}{|l|} 
\\
\\
\end{tabular} & $\left.\right|_{X}$ & 艿 & $\mid z_{0}$ & 訔 & $\left.\right|_{j}$ & 怰 & $z_{0}$ & $\begin{array}{l}\mathbf{z} \\
\mathbf{z}\end{array}$ & $Z_{0}$ & 䏺 & $Z_{D}$ & 㝘 & $Z_{0}$ & $\sum_{0}^{0}$ & 妾 & 訔 & $\sum_{3}^{\circ}$ \\
\hline rocuta crocuta spelaea & 24 & & \begin{tabular}{|l|}
11 \\
\end{tabular} & 4 & 10 & 5 & 98 & 15 & 25 & 8 & 283 & 36 & 9 & 3 & 322 & 37 & 68 & 10 & 850 & 6 & 792 & 121 & 31 \\
\hline anthe & & & & & & & 3 & 2 & & & 7 & 3 & & & 2 & 1 & 1 & 1 & 13 & $<1$ & 13 & 7 & 2 \\
\hline Panther & & & & & & & & & & & & & & & & & & & 1 & $<1$ & 1 & 1 & $<1$ \\
\hline Ursus & & 3 & & & & & 4 & 2 & & & 1 & 1 & & & 7 & 2 & 1 & 1 & 17 & $<1$ & 17 & 9 & 2 \\
\hline Canis lupu. & & & 1 & 1 & 1 & 1 & 4 & 3 & & & 17 & 2 & 1 & 1 & 8 & 2 & 5 & 2 & 37 & $<1$ & 37 & 12 & 3 \\
\hline Vulpes vulpes & 4 & 1 & 3 & 1 & & & 1 & 1 & 1 & 1 & 4 & 1 & & & & & & & 13 & $<$ & 12 & 5 & 1 \\
\hline cf. Alop & & & & & & & & & & & 1 & 1 & & & & & & & 1 & $<1$ & 1 & 1 & $<1$ \\
\hline Vulpe & & & 2 & 1 & 2 & 1 & 13 & 2 & 2 & 2 & 26 & 2 & 2 & 1 & 9 & 1 & 6 & 2 & 62 & $<1$ & 55 & 12 & 3 \\
\hline Gulo & 1 & 1 & 1 & 1 & 2 & 1 & 1 & 1 & & & 2 & 1 & & & & & 2 & 1 & 9 & $<1$ & 9 & 6 & 2 \\
\hline les & & & 1 & 1 & 9 & 2 & 4 & 2 & 5 & 2 & 3 & 2 & & & & & 3 & 1 & 25 & $<1$ & 24 & 10 & 3 \\
\hline Marte & & & & & 1 & 1 & & & & & 1 & 1 & & & & & & & 2 & $<1$ & 2 & 2 & 1 \\
\hline Must & & & & & & & & & & & 2 & 1 & & & & & & & 2 & $<1$ & 2 & 1 & 1 \\
\hline Muste & & & & & 3 & 1 & 1 & 1 & & & 3 & 1 & & & & & 1 & 1 & 8 & $<1$ & 7 & 4 & 1 \\
\hline Camivora (gr & & & 5 & - & 6 & - & 7 & - & 4 & - & 17 & - & 1 & - & 5 & - & 12 & - & 57 & $<1$ & - & - & - \\
\hline Camivora ( $\mathrm{P}$ & & & & & 5 & - & 2 & - & & & 5 & 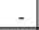 & & & & & 1 & T & 13 & $<1$ & - & - & - \\
\hline$T$ & 33 & 8 & 24 & 9 & 39 & 12 & 138 & 29 & 37 & 13 & 372 & 52 & 13 & 5 & 354 & 44 & 100 & 19 & 1110 & 7 & 972 & 191 & 49 \\
\hline Mammuthu & 3 & 1 & 3 & 1 & 4 & 1 & 20 & & 3 & 1 & 89 & 1 & 5 & 1 & 48 & 2 & 47 & & 22 & & 63 & 8 & 2 \\
\hline Coelodon & 11 & & 1 & 1 & 0 & 1 & 1 & 4 & 3 & 1 & 80 & 10 & 6 & 3 & 72 & 10 & 35 & 7 & 225 & & 178 & 39 & 10 \\
\hline & 6 & 2 & & & 4 & 2 & 6 & 3 & 3 & 1 & 16 & 4 & 1 & 1 & 7 & 2 & 3 & 1 & 46 & $<1$ & & 6 & 4 \\
\hline Cervu: & 4 & 3 & 1 & 1 & 3 & 1 & 0 & 1 & & & 5 & 1 & 1 & 1 & 5 & 1 & 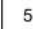 & 1 & 30 & $<1$ & 99 & 10 & 2 \\
\hline & 5 & 1 & & & 3 & 2 & 16 & 1 & 3 & 1 & 38 & 3 & 3 & 2 & 27 & 3 & 18 & 3 & 113 & 1 & 94 & 16 & 4 \\
\hline us capreolus & & & 2 & 1 & & & & & & & 6 & 1 & & & & & 3 & 1 & 11 & $<1$ & 9 & 3 & 1 \\
\hline & & & 1 & 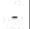 & & & 4 & - & 1 & - & 8 & 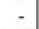 & & & 6 & - & 1 & & 21 & 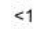 & 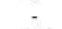 & - & - \\
\hline aballus & 58 & & 8 & 2 & 24 & 3 & 137 & 9 & 29 & 6 & 309 & 16 & 13 & 2 & 228 & 14 & 116 & 10 & 922 & 6 & 827 & 62 & 17 \\
\hline & 3 & & 1 & - & & & 2 & T & & & 7 & - & & & 2 & - & 2 & & 17 & $<1$ & 14 & - & - \\
\hline & 17 & 3 & 1 & 1 & 5 & 1 & 51 & 5 & 9 & 3 & 79 & 8 & 5 & 1 & 58 & 6 & 16 & 3 & 241 & 2 & 191 & 31 & 8 \\
\hline & & & 3 & $\therefore$ & & & 11 & - & & & 17 &. & & & 6 & - & 6 & - & 43 & $<1$ & - & - & - \\
\hline$u_{t}$ & & & 3 & t & 6 & & 17 & - & 11 & - & 35 & - & & & 7 &. & 28 &. & 107 & 1 & - & - & - \\
\hline (moy) & 1 & & 2 & - & 5 & & 8 & - & 8 & - & 21 & - & 3 & - & 15 & . & 31 & - & 94 & 1 & 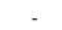 & - & - \\
\hline Ungulata (gra & 3 & t & T & 1 & 5 & & 1 & 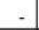 & & - & 39 & - & 1 & t & so & - & 18 & - & 27 & & -5 & - & - \\
\hline Total Ongulé & 111 & 17 & 29 & 7 & 61 & 11 & 308 & 24 & 77 & 13 & 749 & 44 & 38 & 11 & 517 & 39 & 329 & 26 & 2219 & 15 & 1457 & 192 & 49 \\
\hline Lep & 1 & 1 & 1 & 1 & & & & & & & & & & & 1 & 1 & & & 3 & $<1$ & 3 & 3 & 1 \\
\hline & & & & & 1 & 1 & & & & & & & & & & & & & 1 & & 1 & 1 & $<1$ \\
\hline$M a$ & & & 1 & 1 &. & 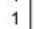 & 7 & & 1 & 1 & 1 & 1 & & & 2 & 1 & & & 14 & $<1$ & 12 & 5 & 1 \\
\hline & & & & & & & & & & & & & & & & & 1 & - & & $<1$ & - & - & - \\
\hline ndéterminè & & & 47 & & 177 & - & 1544 & & 242 & & 4883 & - & 240 & & 2348 & - & 2148 &. & 11629 & 78 & - & - & - \\
\hline tal & 145 & 26 & 102 & 18 & 280 & 25 & 1997 & 53 & 357 & 27 & 6005 & 97 & 291 & 16 & 3222 & 85 & 2578 & 45 & 14977 & 100 & 2445 & 392 & 100 \\
\hline
\end{tabular}

This faunal association indicates an open environment, with the development of a rich grassy steppe, as previously shown by the preliminary study of the assemblage (Fosse 1997). The association of the lemmings Dicrostonyx and Lemmus and the presence of the marmot show that the climate was harsh at this time (Roger, unpublished). The presence of the roe deer, a marker of more temperate climatic phases, evokes the observed sedimentological alternation (cf. supra). The diversified Fouvent faunal list is in all points comparable to that of hyena dens from (sub) contemporaneous chronological phases. The association of carnivores (hyena, lion, wolf, bear and fox), small and medium-sized ungulates (roe deer, reindeer and red deer), large ungulates (horse, bison, megaloceros) and megaherbivores (rhinoceros, mammoth) is recurrent in Wurmian dens, in particular during isotopic stage 3 (e.g. Camiac in Guadelli 1987; les Plumettes in Beauval \& Morin 2010; Unikoté in Michel 2005).

17 From a strictly biochronological point of view, the faunal list from Fouvent is typical of the Wurmian isotopic stage 3, associating gregarious species with a steppic environment (B. priscus, Equus caballus (s.l.), R. tarandus, C. antiquitatis, M. primigenius).

\section{2 - Palaeoecology}

\subsection{1 - Predator mortality structure (hyena)}

18 The structure of hyena mortality is described as a fundamental characteristic of den characterization (Fosse 1994; Pickering 2002; Kuhn, Berger, Stiner 2008). The presence of juveniles is regularly mentioned as characterizing a den sensu lato. Conversely, adult 
dominance is considered to be typical of feeding zones or simply proof of their presence in an assemblage (Discamps 2011). In spite of this distinction, precise definitions of hyena populations are rare and the mere presence of a particular age class cannot define a set of individuals, or the origin and function of an assemblage.

If we consider that each layer of the site represents a distinct occupation, the hyena remains from Fouvent, including dental $(\mathrm{NR}=732)$ and post-cranial remains $(\mathrm{NR}=118)$, represent a total of 121 individuals minimum. Given the number of animals represented in each layer, the estimated packs are about the same size as those observed for the modern spotted hyena, generally between 15 and 20 individuals per clan. The "clans" at Fouvent vary from 4 (layer E) to 37 individuals (layer C), with an average of 15 hyenas per level. However, for this, we must assume that each sedimentologically defined archaeological level corresponds to a single and once-off occupation. If the MNI is calculated from the total number of bone and dental remains, considering the site as a homogeneous assemblage, the MNI is 56 (20 juveniles (D/4) and 36 adults and old adults (M/1)). Moreover, the same comments apply to all of the taxa. However, in the absence of elements indicating the grouping of the different layers, we consider that the stratigraphic division reflects multiple predator occupations. The hypothesis of a total population of 121 hyenas corresponding to different packs is thus favoured here. The observation of dental wear (732 elements) and the number of individuals considered (114 MNI identified from the dental material) enables us to establish a detailed definition of population structure (tab. 3).

The overall structure of the Fouvent population is dominated by juveniles (37 MNI). The use of ternary modelling does not seem to modify this observation. Thus, even if we consider that half of the individuals from stage 2 (or nine animals) are adults, juveniles still dominate the overall population $(\mathrm{MNI}=46)$, followed by adults $(\mathrm{MNI}=34)$ and old adults (MNI=34). This den thus seems to have been used as a nursery. Moreover, while the abundance of hyena remains is an important criterion for the characterization of Pleistocene dens, out of 270 known present-day dens (Crocuta=139, Hyaena $=63$, Parahyaena $=68$ ), only 27 contain hyena bone remains (summary in Fourvel 2012). The evolution of spotted hyena behaviour since the Pleistocene may explain this difference between fossil and modern assemblages. The occupation duration of a den by a pack of present-day hyenas is short (less than 4 months for the spotted hyena in Mills 1990), thereby limiting mortality in the den. Pleistocene populations (often with considerable NR and MNI) do not use sites for a single occupation but multiple episodes and therefore it is difficult to estimate the number and the duration of occupations. In addition, it is important not to overlook the role of the environment and climatic variations, which lead to modifications in faunal lists (available biomass), as they can cause behavioural differences between two closely phylogenetically related sub-species (larger pack size and longer den occupation during the Pleistocene).

\subsection{2 - Mortality structure of prey (ungulates)}

21 The structure of ungulate populations is presented in figure 5 and table 4 . If we take account of prey size classes, the analysis suggests differential selection of the hunted/ consumed age classes. Thus, although the population is small (MNI=3), all of the small ungulates are represented by adults (the consumption and complete digestion of juvenile animals cannot be ruled out, however, no skeletal or dental element related to this age class has been observed, whereas for other taxa, milk teeth and tooth 
fragments have been identified). The distribution of middle and large-sized prey is more balanced, with higher proportions of juveniles and old animals. When the four main groups in the assemblages are taken into account individually (rhinoceros, large bovids, horse, deer and reindeer), the relationship between predator and prey is clearly different from one taxon to another.

Table 3 - Cave hyena mortality structure.

\begin{tabular}{|l|c|c|c|c|c|}
\hline & Stade 1 & Stade 2 & Stade 3 & Stade 4 & Stade 5 \\
\cline { 2 - 6 } & Juvénile & Sub-adulte & Adulte & Adulte âgé & Sénile \\
\hline NMI & 37 & 18 & 25 & 19 & 15 \\
\hline$\%$ NMI & 32 & 16 & 22 & 17 & 13 \\
\hline
\end{tabular}

Figure 5 - Ternary plot of ungulate population structure from Fouvent based on size classes (small, medium, large) and the four main prey (rhinoceros, red deer, horse, bovid).

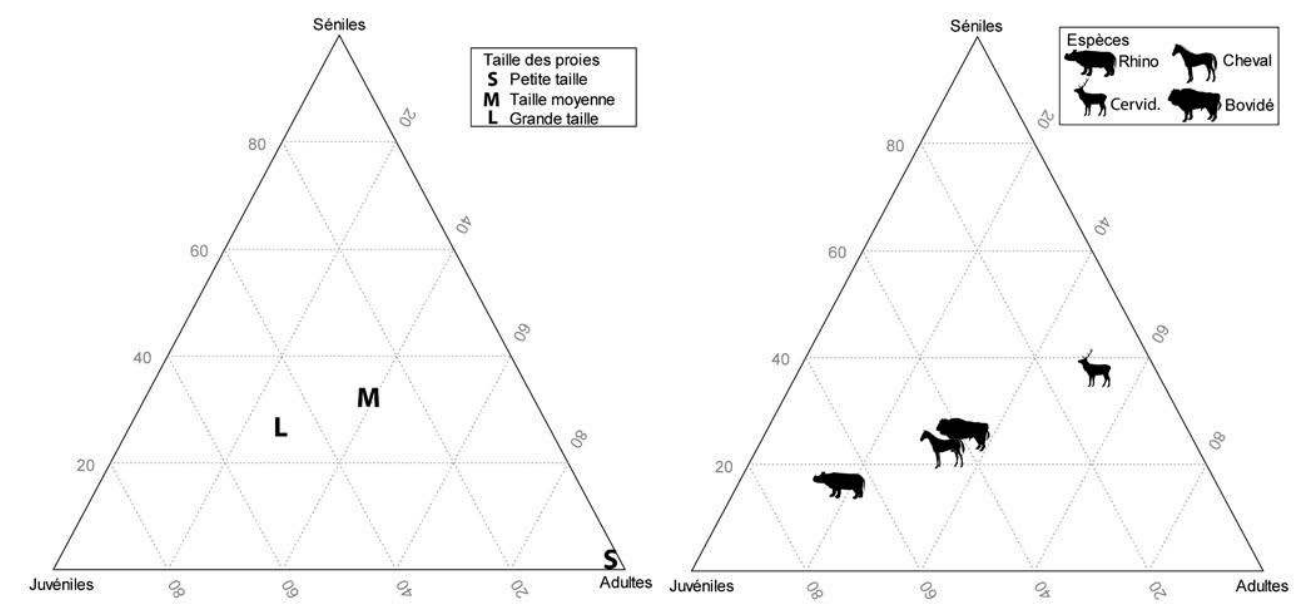

Table 4 - Ungulate population structure from Fouvent (MNI based on dental material; $x / y=M N I /$ $\% \mathrm{MNI})$.

\begin{tabular}{|l|c|c|c|c|c|c|}
\hline Classe de taille & Petit & Moyen & \multicolumn{3}{|c|}{ Grand } & Méga. \\
\hline $\begin{array}{l}\text { Groupe } \\
\text { spécifique }\end{array}$ & Cervidé (petit) & $\begin{array}{c}\text { Cervidé } \\
\text { (moyen) }\end{array}$ & Equidé & $\begin{array}{c}\text { Cervidé } \\
\text { (grand) }\end{array}$ & Bovidé & Rhino. \\
\hline Juvénile & & $5 / 19$ & $12 / 40$ & $3 / 19$ & $13 / 19$ & $23 / 66$ \\
\hline Adulte & $3 / 100$ & $11 / 42$ & $10 / 33$ & $4 / 25$ & $11 / 33$ & $6 / 17$ \\
\hline Sénile & & $10 / 38$ & $8 / 27$ & $9 / 56$ & $9 / 27$ & $6 / 17$ \\
\hline$\underline{\text { Total }}$ & $\underline{\mathbf{3}}$ & $\underline{\mathbf{2 6}}$ & $\underline{\mathbf{3 0}}$ & $\underline{16}$ & $\underline{\mathbf{3 3}}$ & $\underline{\mathbf{3 5}}$ \\
\hline
\end{tabular}

In this way, megaherbivores, such as the rhinoceros, are mainly represented by juveniles (MNI=23; $66 \% \mathrm{MNI}$ ) with smaller proportions of adults and old adults. As the size of the species decreases, the frequency of adults and old adults increases. Figure 5 illustrates this phenomenon: medium-sized cervids (reindeer and red deer) present a higher rate of adults (MNI=11; $42 \% \mathrm{MNI})$ and old adults $(\mathrm{MNI}=10 ; 38 \% \mathrm{MNI})$ and a lower frequency of juveniles (MNI=5; 19 \%MNI). Prey size plays a significant role in acquisition strategies (hunting, scavenging) and in the selected and consumed age 
classes. The larger the prey, the more the hyena attacks young specimens (which are proportionally smaller). Conversely, when prey size is smaller, the hyena is more likely to attack adults.

\section{3 - Skeletal representation of prey}

Isolated teeth, resulting from skull and mandible fragmentation, are the most frequent skeletal elements as they are the most resistant. In order to avoid bias related to the over-representation of these elements, isolated teeth were excluded from ungulate skeletal distribution. Figure 6 and table 5 present the skeletal distribution of small (roe deer), medium-sized (reindeer, red deer), large (megaloceros, horse, bovidae) and very large prey (rhinoceros). Roe deer are poorly represented ( $N R=10 ; N M E=8)$. Only the appendicular skeleton is present, with a majority of hind leg elements (NR=6; NME=5). Skeletal distribution is slightly different for medium-sized species (reindeer and red deer).

Figure 6 - Skeletal distribution of prey (roe deer, large cervid, equid, bovidae, rhinoceros) expressed in \%NISP and \%MNE (excluding isolated teeth). Skeleton profiles drawn by M. Coutureau et alii (๑) 1996-2012 ArchéoZoo.org).

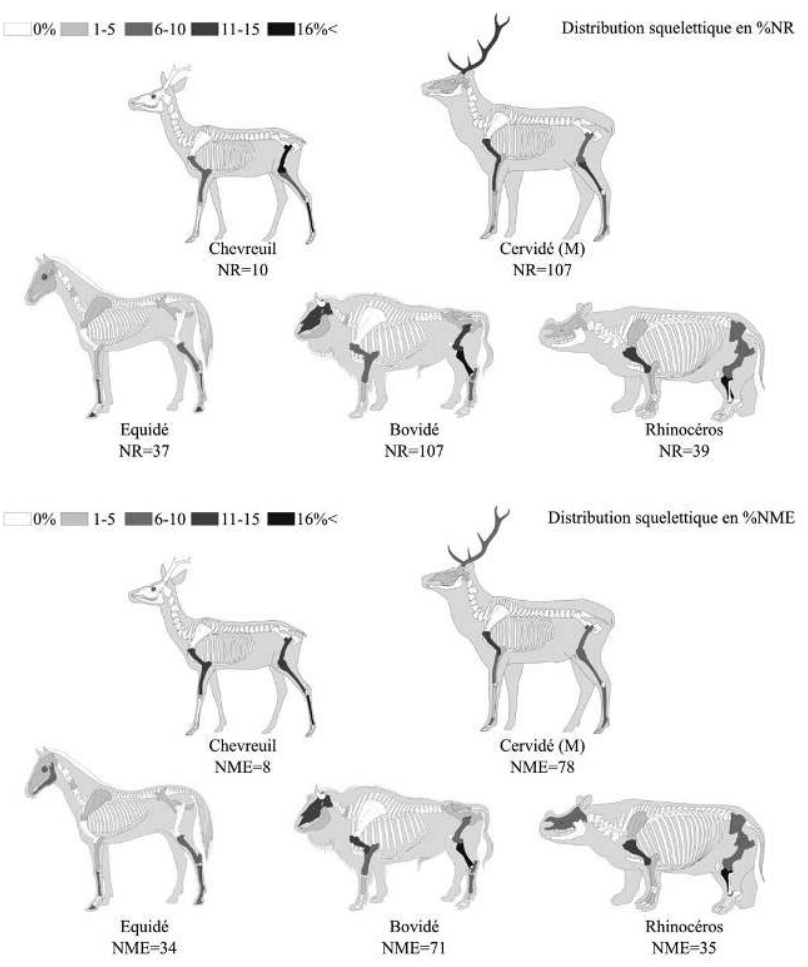


Table 5 - Skeletal part distribution for small, medium, large-sized ungulates and megaherbivores (NISP(\%NISP)/ MNE(\%MNE)).

\begin{tabular}{|l|c|c|c|c|}
\hline & Petite proie & Proie moyenne & Grande Proie & Mégaherb. \\
\hline Bois & & $15(14) / 8(10)$ & & \\
\hline Crâne & & $3(3) / 2(3)$ & $14(10) / 11(10)$ & $2(3) / 2(4)$ \\
\hline Maxillaire & & $1(1) / 1(1)$ & $1(<1) / 1(1)$ & \\
\hline Mandibule & & & $3(2) / 3(3)$ & \\
\hline Cervicale & & & $3(2) / 3(3)$ & $1(2) / 1(2)$ \\
\hline Thoracique & & & & $2(3) / 2(4)$ \\
\hline Sacrum & & & $1(<1) / 1(1)$ & \\
\hline Scapula & & & $1(<1) / 1(1)$ & $1(2) / 1(2)$ \\
\hline Humérus & $1(10) / 1(12,5)$ & $14(13) / 11(14)$ & $11(8) / 9(8)$ & $6(11) / 5(11)$ \\
\hline Radius & $1(10) / 1(12,5)$ & $10(9) / 7(9)$ & $10(7) / 5(5)$ & $3(5) / 2(4)$ \\
\hline Radio-ulna & & & $1(<1) / 1(1)$ & \\
\hline Ulna & $1(10) / 1(12,5)$ & $1(1) / 1(1)$ & $3(2) / 2(2)$ & $1(2) / 1(2)$ \\
\hline Carpien & & $4(4) / 4(5)$ & $4(3) / 4(4)$ & \\
\hline Métacarpe & & $2(2) / 2(3)$ & $6(4) / 6(5)$ & $1(2) / 1(2)$ \\
\hline Pelvis & & & $2(1) / 2(2)$ & $5(9) / 3(7)$ \\
\hline Fémur & $2(20) / 1(12,5)$ & $9(8) / 7(9)$ & $13(9) / 6(5)$ & $7(13) / 5(11)$ \\
\hline Patella & & $1(1) / 1(1)$ & & $2(3) / 2(4)$ \\
\hline Tibia & $1(10) / 1(12,5)$ & $12(11) / 7(9)$ & $26(18) / 14(13)$ & $19(34) / 15(33)$ \\
\hline Calcanéus & & & $8(5) / 8(7)$ & $1(2) / 1(2)$ \\
\hline Talus & $1(10) / 1(12,5)$ & $2(2) / 2(3)$ & $5(3) / 5(5)$ & $2(3) / 2(4)$ \\
\hline Tarsien & & $2(2) / 2(3)$ & $3(2) / 3(3)$ & \\
\hline Métatarse & $3(30) / 2(25)$ & $7(6) / 5(6)$ & $10(7) / 8(7)$ & \\
\hline Phalange 1 & & $8(7) / 6(8)$ & $4(3) / 4(4)$ & $1(2) / 1(2)$ \\
\hline Phalange 2 & & $5(5) / 4(5)$ & $2(1) / 2(2)$ & \\
\hline Phalange 3 & & $4(4) / 2(3)$ & $4(3) / 3(3)$ & \\
\hline Métapode & & $7(6) / 6(8)$ & $9(6) / 8(7)$ & $1(2) / 1(2)$ \\
\hline Total NR/NME & $10 / 8$ & $107 / 78$ & $144 / 110$ & $55 / 45$ \\
\hline
\end{tabular}

24 The appendicular skeleton is still predominant (forelimb = $29 \% \mathrm{NR}, 32 \% \mathrm{NME}$; hindlimb $=30 \% \mathrm{NR}, 31 \% \mathrm{NME}$ ). However, cranial elements represent $18 \%$ of the material (14 $\% \mathrm{NME}$ ), with antler alone comprising $14 \%$ (10 \%NME). Cervid antler is often mentioned in the European Pleistocene (e.g. Camiac in Guadelli 1987; Lunel-Viel 1 in Fosse 1994; Tournal in Magniez 2010), and is considered by some authors as a den-characterizing criterion (Buckland 1822; Stiner 1991).

Whatever the species (red deer, reindeer, megaloceros), gnawed antler systematically presents a similar modification: the base and one or both of the first antler shafts are heavily chewed. The appendicular skeleton is also predominant for large prey (forelimb $=25 \% \mathrm{NR}, 25 \% \mathrm{NME}$; hindlimb = $44 \% \mathrm{NR}, 44 \% \mathrm{NME})$. The cranial (NR=18; NME=15) and axial elements ( $\mathrm{NR}=7 ; \mathrm{NME}=7)$ represent a considerable proportion of skeletal distribution (13\%NR, 14\%NME and $4 \% \mathrm{NR}, 7$ \%ME respectively).

Megafaunal skeletal distribution (rhinoceros and mammoth) is clearly different to that of other prey: the rear appendicular skeleton is largely dominant (55\%NR, $54 \% \mathrm{NME}$ ); the fore appendicular and axial skeleton values are relatively close $(20 \% \mathrm{NR}, 19 \% \mathrm{NME}$ and $16 \% \mathrm{NR}, 15 \% \mathrm{NME}$ respectively); cranial elements are underrepresented (3\%NR, 4 \%NME). Whereas earlier works correlate skeletal distribution to prey size (e.g. Binford 1981; Fosse 1994), at Fouvent appendicular elements are systematically dominant, regardless of prey size. These skeletal distributions may reflect predator choice to preferentially collect and consume limbs, which contain more flesh than cranial and axial skeletons (cf. infra 5. Discussion). 


\section{4 - Taphonomic analysis}

\subsection{1 - Long bone breakage}

Among the 165 long bones (or fragments) included in this analysis, we distinguished six bone portions (to which we can add the whole elements): isolated proximal or distal extremities associated with shaft elements, shaft cylinders, diaphyseal shards. Table 6 presents the distribution (NR/NME) and the frequency (\%NR/\%NME) of each portion for each long bone and specific group. Based on this data, it is possible to observe i) differential treatment for each bone considered and ii) variations according to hyena prey. Diaphyseal shards are the most frequent elements; they represent from 70 to $92 \%$ of the NR and 59 to $86 \%$ of the NME of bones with high meat content (humerus, radius, femur, tibia). Shaft cylinders are well represented but are far from the most frequent portions ( 4 to $25 \% \mathrm{NR} ; 7$ to $33 \% \mathrm{NME}$ ). Generally speaking, given the distribution of the remains in the different stratigraphic levels, the distribution and frequency of these different portions calculated from the NME do not appear to underline any significant difference with the NR data (even if they slightly temper these results). Extremities are poorly represented (variation from 4 to $6 \% \mathrm{NR}$ and 6 to $8 \% \mathrm{NME}$ ) and whole bones are completely absent.

Metapodial bones (metacarpals and metatarsals) show different distribution: proximal extremities with shafts represent nearly $30 \%$ of the material ( $29 \% \mathrm{NME}$ ), whole bones and diaphyseal shards almost a quarter each and cylinders are absent. The fragmentation rate of the different long bones may be linked to the quantity of meat available on each piece. Due to the small quantity of meat or fat in metapodial bones, hyenas did not exploit these elements completely and abandoned them quickly. Medium to large sized prey (cervid / equid-bovid) follow the same model: for bones "rich" in meat, fat and marrow), diaphyseal shards are dominant with less reduction for metapodial bones. For the rhinoceros, on the other hand, bone reduction is different.

In spite of the small size of the rhinoceros sample (NR=26, NME=25), long bones are less fragmented: humerus ( $\mathrm{NR}=5, \mathrm{NME}=5)$, femur $(\mathrm{NR}=2, \mathrm{NME}=2)$ or tibia cylinders $(\mathrm{NR}=13$, $\mathrm{NME}=12$ ) are frequent. This difference in treatment compared to other prey seems to correspond to the same reasoning as the distinction between "rich" bones and metapodial bones. The thickness of cortical bone, which is significant for the rhinoceros, may also play a role. However, the quantity of meat on the zeugopod and the autopod is higher than for other taxa, leading to less reduction and fragmentation of appendicular elements by the predator.

The epiphyseal/diaphyseal ratios obtained for the "rich" bones from each category are low: 0.02 for medium-sized taxa (deer and reindeer), 0.05 for large prey (horses and bovids) and 0.04 for the rhinoceros. These results are comparable to the model defined by Blumenschine (1988) with a very low epiphyseal/diaphyseal ratio (0.03), only in cases with carnivore impact. The over consumption of extremities with high fat content may explain the underrepresentation of these elements. Unlike the "rich" bones, the epiphyseal/diaphyseal ratios for metapodial bones are much higher (2.7 for medium-sized prey and 1.8 for large prey), confirming the low exploitation of these elements. In this way the Fouvent hyena chooses how to consume the different anatomic elements depending on the quantity of meat and fat in each bone element. Note however that the overconsumption of extremities by carnivores is not a general 
rule and depends on meat availability. In this way, in spite of the abundance of prey in Djibouti (mainly domestic livestock), the present-day spotted hyena does not only exploit long bones (Fourvel 2012); the epiphyseal/diaphyseal ratios recorded in five modern dens are 1.07 (Dumali), 1.8 (Heraide), 1 (Yangula Ari) and 1.53 (Oboley) respectively.

The analysis of long bone fragmentation based on the method established by Bunn (1983) is in agreement with the notion of differential consumption depending on i) the type of element considered (rich or poor) and ii) prey size (fig. 7). Whatever criteria are taken into consideration (shaft circumference, extremities, shaft length, with or without extremities), medium-sized long bones at Fouvent are very fragmented. The proportions of most of the material are low (circumference and length $<1 / 2$ ). This high fragmentation can be interpreted as the result of an overexploitation of the appendicular elements of medium-sized prey. When the quantity of meat on the bone is insufficient for the predator, the hyena breaks long bones as much as possible in order to extract the nutritional qualities from the bone and marrow. Long bone breakage in large prey is different and seems to be more variable depending on the criterion or bone considered.

Table 6 - Distribution of the various long bone portions in cervids, equids, bovids and rhinoceros (NISP/MNE and \%NISP/\%MNE).

\begin{tabular}{|l|c|c|}
\hline Os & \multicolumn{2}{|c|}{ Humérus } \\
\hline Portion & Cylindre & Eclat \\
\hline Cervidé & & $14 / 11$ \\
\hline Equidé & & \\
\hline Bovidé & $2 / 2$ & $9 / 7$ \\
\hline Rhinocérotidé & $5 / 5$ & $1 / 1$ \\
\hline Total NR / NME & $\mathbf{7 / 7}$ & $\mathbf{2 4 / 1 9}$ \\
\hline \%NR/\%NME & $\underline{\mathbf{2 3 / 2 7}}$ & $\underline{\mathbf{7 7 / 7 3}}$ \\
\hline
\end{tabular}

\begin{tabular}{|c|c|c|}
\hline \multicolumn{3}{|c|}{ Radio-ulna } \\
\hline Prox + d. & Cylindre & Eclat \\
\hline & & $10 / 7$ \\
\hline & & $1 / 1$ \\
\hline $1 / 1$ & & $9 / 4$ \\
\hline & $1 / 1$ & $1 / 1$ \\
\hline $\mathbf{1 / 1}$ & $\mathbf{1 / 1}$ & $\mathbf{2 1 / 1 3}$ \\
\hline$\underline{\mathbf{4} / 7}$ & $\underline{\mathbf{4 / 7}}$ & $\underline{\mathbf{9 2 / 8 6}}$ \\
\hline
\end{tabular}

\begin{tabular}{|l|c|c|c|}
\hline Os & \multicolumn{3}{|c|}{ Fémur } \\
\hline Portion & Cylindre & Eclat & Dist \\
\hline Cervidé & & $8 / 6$ & $1 / 1$ \\
\hline Equidé & & & \\
\hline Bovidé & & $13 / 6$ & \\
\hline Rhinocérotidé & $2 / 2$ & $1 / 1$ & \\
\hline Total NR / NME & $\mathbf{2 / 2}$ & $\mathbf{2 2 / 1 3}$ & $\mathbf{1 / 1}$ \\
\hline \%NR/\%NME & $\underline{\mathbf{8 / 1 3}}$ & $\underline{\mathbf{8 8 / 8 1}}$ & $\underline{\mathbf{4} 6}$ \\
\hline
\end{tabular}

\begin{tabular}{|c|c|c|}
\hline & Tibia \\
\hline Cylindre & Eclat & Dist + d. \\
\hline & $12 / 7$ & \\
\hline & $2 / 1$ & $1 / 1$ \\
\hline & $22 / 12$ & $1 / 1$ \\
\hline $13 / 12$ & $1 / 1$ & $1 / 1$ \\
\hline $\mathbf{1 3 / 1 2}$ & $\mathbf{3 7 / 2 1}$ & $\mathbf{3 / 3}$ \\
\hline$\underline{\mathbf{2 5 / 3 3}}$ & $\underline{\mathbf{7 0 / 5 9}}$ & $\underline{\mathbf{6 / 8}}$ \\
\hline
\end{tabular}

\begin{tabular}{|l|c|c|c|c|c|c|}
\hline Os & \multicolumn{6}{|c|}{ Métapode } \\
\hline Portion & Complet & Prox & Prox + d. & Eclat & Dist +d. & Dist \\
\hline Cervidé & $2 / 2$ & $1 / 1$ & $3 / 3$ & $3 / 2$ & $1 / 1$ & $3 / 2$ \\
\hline Equidé & $3 / 3$ & & $2 / 2$ & & & \\
\hline Bovidé & $3 / 3$ & & $4 / 3$ & $5 / 3$ & $2 / 2$ & $1 / 1$ \\
\hline Rhinocérotidé & - & - & - & - & - & - \\
\hline Total NR / NME & $\mathbf{8 / 8}$ & $\mathbf{1 / 1}$ & $\mathbf{9 / 8}$ & $\mathbf{8 / 5}$ & $\mathbf{3 / 3}$ & $\mathbf{4 / 3}$ \\
\hline \%NR/\%NME & $\underline{\mathbf{2 4 / 2 9}}$ & $\underline{\mathbf{3 / 4}}$ & $\underline{\mathbf{2 8 / 2 9}}$ & $\underline{\mathbf{2 4 / 1 8}}$ & $\underline{\mathbf{9 / 1 0}}$ & $\underline{\mathbf{1 2 / 1 0}}$ \\
\hline
\end{tabular}

The comparison of the breakage recorded at Fouvent with that of the sub-synchronous den of Conives (Fourvel 2012) and the Middle Pleistocene site Lunel-Viel 1 (Fosse 1994) leads to other observations. These samples present differential impact on the length and circumference. At Lunel-Viel 1, the circumferences of both types of slightly reduced bones point to slight bone breakage. On the other hand, length is more significantly reduced on "rich" bones than on poorer bones (lower proportion of whole bones for the first type). Although breakage at Conives appears to be quite similar to 
that recorded at Fouvent, it is nonetheless more intensive. Lunel-Viel 1 presents a lower breakage rate.

\subsection{2 - Carnivore marks}

Figure 7 - "Poor" and "rich" long bone fragmentation for medium-sized and large-sized prey from Fouvent and comparisons with other Pleistocene samples (Lunel-Viel I in Fosse 1994; Conives in Fourvel 2012).

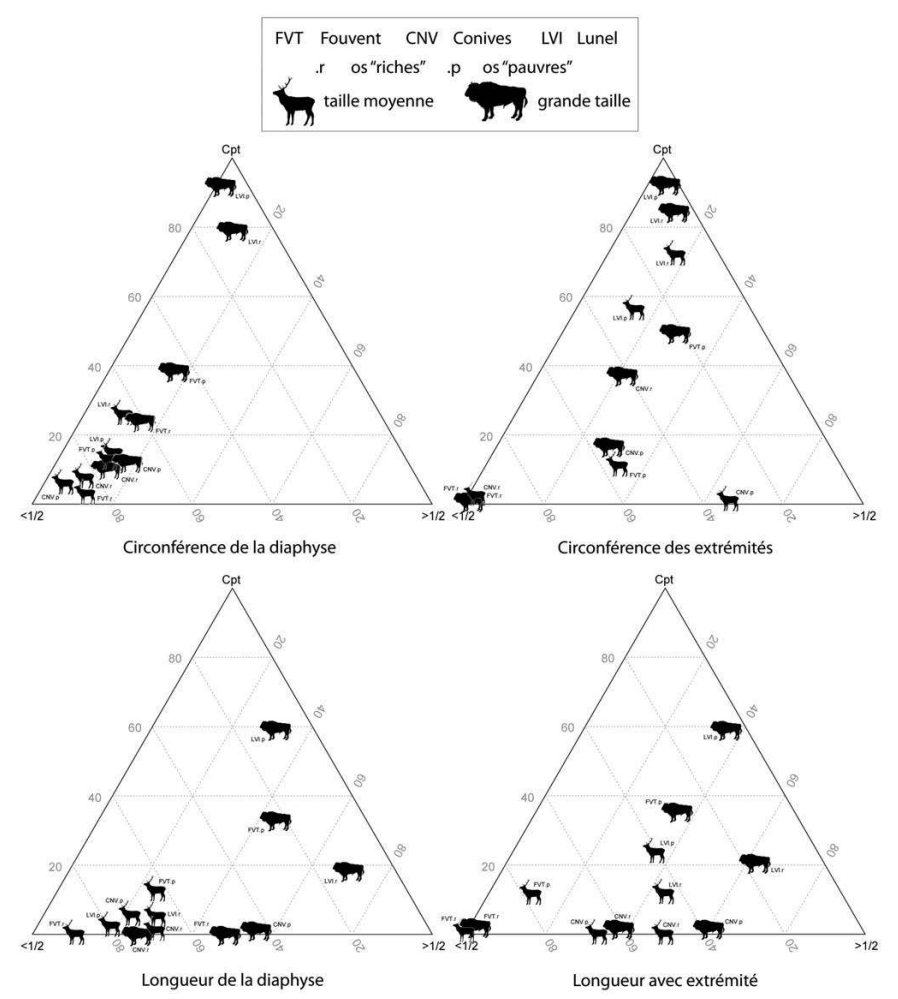

Predators produce diverse well-known consumption marks (e.g. Sutcliffe 1970; Binford 1981; Brain 1981). These denote a range of actions related to consumption and the bone reduction sequence (impact marks, scraping, reduction and ingestion). The osteologic material from Fouvent presents the whole range of known marks (tab. 7). Note however that in spite of the presence of a lithic series (300 pieces including cores, tools, flakes), no anthropogenic marks (striations) were observed on the bone material. The absence of striations can result from taphonomic bias (bone surface alteration), but can also be due to the fact that there is no link between the bone deposit and the lithic material. The introduction of the latter into the pre-existing site can result from different external factors (Discamps 2011).

Carnivore marks affect 1811 bone remains, or $12.4 \%$ of the observable NR (including teeth). A total of 2166 surface alterations produced by carnivores were identified (tab. 7). Altogether, 489 of the consumed remains are ungulate elements, or $24 \%$ of the total number of observable ungulate prey remains. The species affected by these marks are very diversified and include the reindeer $(\mathrm{NR}=31)$ and the deer $(\mathrm{NR}=3)$, as well as the rhinoceros $(\mathrm{NR}=3)$ and the mammoth $(\mathrm{NR}=7)$.

The differential representation of each type of mark (punctures, pitting, scooping out, ...) can result from different factors. Eco-ethologic causes can contribute to the different representation rates of certain marks. The combined influence of pack size, 
prey availability and potential food stress can lead to higher reduction rates and consequently to variations in certain types of alterations. In this respect, the low occurrence of furrow type friction marks (scraping marks on epiphyses) or scooping out type reductions (tearing away part of the epiphysis in order to consume the spongiosa) appear to be related to an overconsumption of bone extremities. Conversely, the predominance of pitting type impact marks and fracture scars corresponds to an intensive exploitation of bone material (in particular long bone reduction and the considerable proportion of diaphyseal elements), which can indicate a form of food stress, forcing the predator to extreme bone consumption. At Fouvent, the rate of ingested bone is very high (tab. 7).

This large quantity of material raises the question of the origin of these pieces: coprocenose versus regurgitation.

As no coprolites have been preserved at the site (a priori due to conservation issues), it is difficult to identify phenomena strictly linked to coprocenose. The examination of all the osteologic material (including sieve residues) brought to light the overrepresentation of bone shards of less than $30 \mathrm{~mm}$ (tab. 8). In the modern record, there is a differential representation of bone fragments (of more and less than $3 \mathrm{~cm}$ ) and ingested bone shards. Large-sized pieces represent 47 to $67 \%$ of regurgitated bones compared to $10 \%$ in feces; shards are present in $60 \%$ of regurgitations as opposed to 63 $\%$ in feces (Bearder 1977). It is thus legitimate to assume that the frequent small bone shards at Fouvent are the result of coprocenose whereas larger determinable pieces would come from regurgitation. The length distribution of ingested bones indicates an overrepresentation of shards less than $30 \mathrm{~mm}$ (fig. 8). On account of this distribution and actualist observations, it is more likely that these bones result from coprocenose than regurgitation.

\section{5 - Discussion}

Table 7 - Distribution of the different types of bone modification resulting from hyena consumption.

\begin{tabular}{|l|c|c|c|c|c|c|}
\hline \multirow{2}{*}{} & \multicolumn{2}{|c|}{ Impact } & \multicolumn{3}{c|}{ Fracturation/Réduction } & Frottement \\
\cline { 2 - 7 } & Punctures & Pitting & Scooping & Crenulated & Fract. Scars & Score/Furrow \\
\hline NR & 44 & 205 & 5 & 16 & 164 & 20 \\
\hline$\%$ NRD & $1,3 \%$ & $6,0 \%$ & $0,2 \%$ & $0,5 \%$ & $5,0 \%$ & $0,6 \%$ \\
\hline$\%$ NRT & $0,3 \%$ & $1,4 \%$ & $0,1 \%$ & $0,1 \%$ & $1,0 \%$ & $0,1 \%$ \\
\hline N Traces & 81 & 254 & 5 & 16 & 313 & 60 \\
\hline
\end{tabular}

Table 8 - Distribution of the different ingested skeletal parts.

\begin{tabular}{|c|c|c|c|c|c|c|}
\hline Crâne & Dent & Carpe/Tarse & Phalange & Os long & Esquille & Autre \\
\hline 29 & 127 & 19 & 22 & 54 & 1176 & 10 \\
\hline
\end{tabular}


Figure 8 - Distribution of the length of ingested remains.

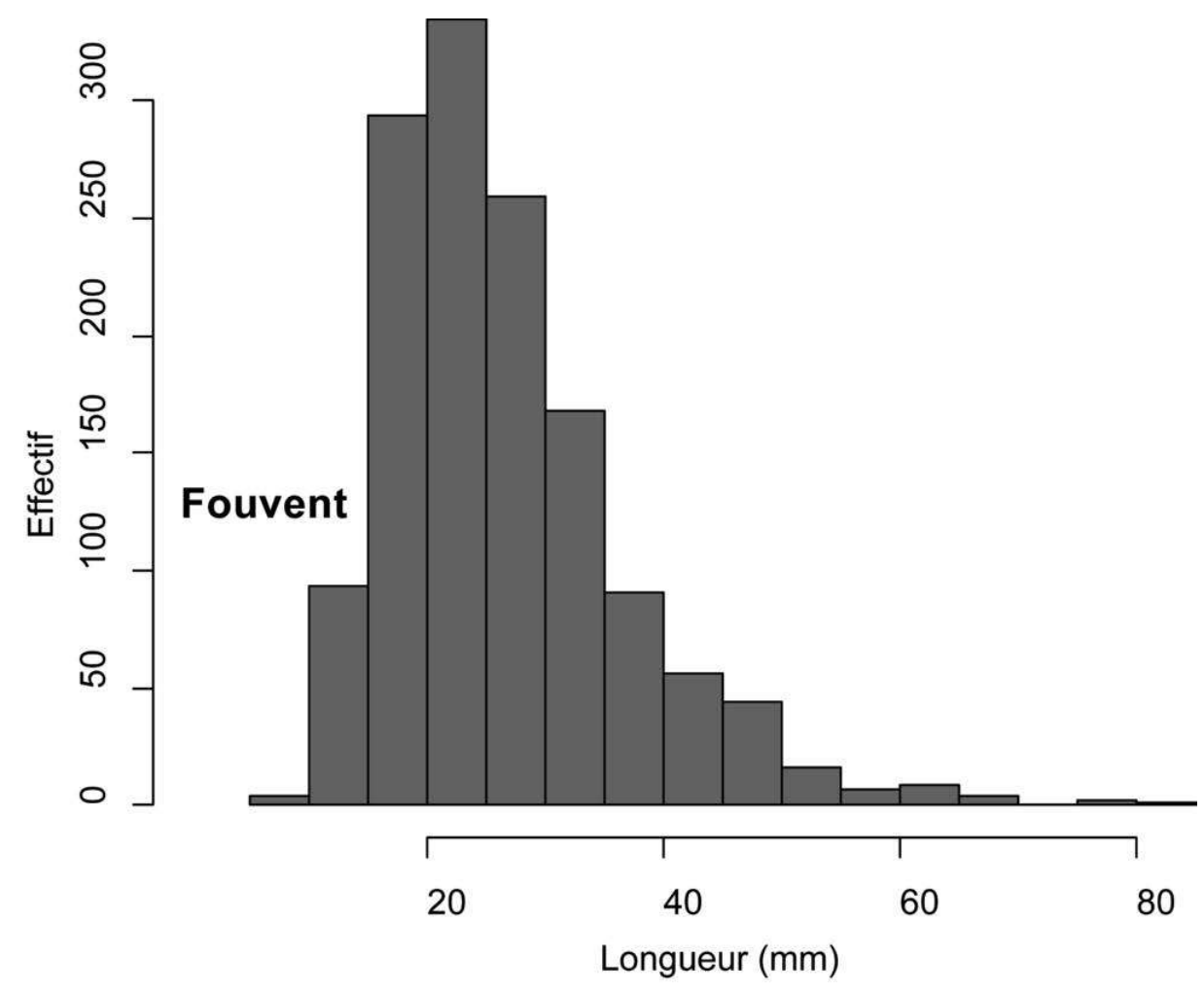

The taphonomic examination of the Fouvent bone accumulation is part of the wider question of the characterization of Pleistocene hyena dens and the impact of large predators on bone stocks. Since founding taphonomic works on hyenids (e.g. Zapfe 1939) and the identification of the role of the hyena in the formation of osteologic assemblages (Thenius 1961), several interpretative grids for dens have been developed with a view to characterizing the taphonomic signature of the predator (Bunn 1983; Cruz-Uribe 1991; Fosse 1994; Pickering 2002; Kuhn, Berger, Skinner 2008; Discamps 2011). However, none of these works - in particular the most recent - summarizes all the former characterizations (since the $20^{\text {th }}$ century) or really takes each criterion into account. For example, work carried out by T. Pickering (2002) or B. F. Kuhn and collaborators (2008) does not discuss the interpretative grids developed by K. CruzUribe (1991) or M. Stiner (1991) and does not take earlier works (e.g. Buckland 1822) or francophone studies (e.g. Fosse 1994) into consideration. Whereas the grid defined by $\mathrm{Ph}$. Fosse (1994) is generally used in Western Europe (and in France in particular), the typology of K. Cruz-Uribe (1991) is favoured by Anglophone authors. In addition, research has shown that the hyena is not the only carnivore capable of interacting with bone stock; all large carnivores can alter bone (canids, felids, hyenids, ursids). As suggested by den characterization criteria, carnivore species are relatively diversified in Pleistocene accumulations. However, taphonomic analyses rarely take into account the potential impact of other predators (Brugal 2010).

Although the analysis of the Fouvent site cannot, on its own, lead to the characterization of the impact of each potential actor, it enables us to review the pertinence of certain criteria used in den characterization. This study allowed us to broach several fundamental aspects, widely used in the literature related to carnivore 
sites: i) prey population structure, ii) the skeletal part distribution of prey, iii) long bone fragmentation and iv) consumption marks.

i. Age-specific prey consumption (e.g. juveniles or old adults), is often associated with the hyena in the literature, but this does not seem to be constant in the modern or fossil record (cf. at Fouvent with equids, Fernandez, Guadelli, Fosse). According to certain authors, prey mortality profiles follow a "U" curve, referred to as attritional (Buckland 1822; Cruz-Uribe 1991), whereas others define them as very variable and closely linked to prey size (Pickering 2002; Discamps 2011; Fourvel 2012). The examination of the faunal profiles from Fouvent is in keeping with the second hypothesis; i.e., that mortality profiles are variable and correlated to prey size. In light of this, the adult rhinoceros remains from Fouvent probably result from scavenging (the ratio between expenditure and gain being largely in the hyena's favour, in this case). In present-day records, when the spotted hyena hunts megafauna (rhinoceros, elephant, giraffe), it favours juveniles (Salnicki et al. 2001).

The energy expenditure caused by hunting medium-sized adult ungulates must be compensated by the quantity of meat provided by the prey. In the fossil record, mortality profiles for bovids, equids and cervids from the sub-contemporaneous sites of Camiac and La Chauverie (Discamps 2011), or older sites such as Lunel-Viel 1 (Fosse 1994), confirm this variability, which appears to be due to modifications in gathering and predation modes. These behavioural variations can result from different factors, such as environmental conditions, prey availability, the size and structure of hyena packs, the occupation duration of a den or the predators competing for access to the same resources.

ii. The contribution of the skeletal part distribution of prey in identifying carnivore sites has been widely discussed using simple frequency observation (Fosse 1994), as well as more complex statistical analyses (Dominguez-Rodrigo \& Pickering 2010). Work carried out up until now has shown that a link appears to exist between prey size and skeletal part distribution leading to the identification of the role of carnivores (Binford 1981; Cruz-Uribe 1991). However, Kruuk (1972) made observations contradicting this criterion and Pickering (2002), in turn, challenged the criterion used by Cruz-Uribe (1991). The present-day assemblages in Djibouti studied by one of us (JBF) also show variability in skeletal part representation (Fourvel 2012). The bone material unearthed at Fouvent does not correspond to this model either; appendicular elements are overrepresented with no significant distinction in relation to prey size. This could result from post-depositional taphonomic phenomena and from the poor conservation of more fragile cranial and axial elements, or from difficulties related to anatomic identification and the specific attribution of axial skeletal elements, or from a behavioural hyena trait, involving the preferential transport of elements of the appendicular skeleton after predation and in situ consumption, or iv) from a combination of two or more of these hypotheses. However, the distribution of middle-sized (cervids) and large ungulates (equids, bovines) from Chauverie (data in Discamps 2011) or Plumettes (data in Beauval and Morin 2010) is comparable to that from Fouvent. As appendicular elements are the most frequent, regardless of prey type, this fact could be explained by behavioural reasons (apart from their meat content). For example, the presentday striped hyena limits competition between predators by bringing as many remains from prey/carcasses as possible back to its den (Ilany 1975). In this respect, the diversity of carnivores during the course of the Upper Pleistocene (lion, panther, wolf, dhole, bear) may explain the adaptive strategy of the cave hyena in response to risks of competition with other predators (human and non-human).

iii. The existing guides emphasize the recurrent presence of sub-complete long bones, the abundance of diaphyseal cylinders and the low fragmentation of these elements (Bunn 1983; Cruz- Uribe 1991; Fosse 1994; Pickering 2002; Kuhn, Berger, Skinner 2008; Discamps 2011). According to these different authors, these consumption morphotypes appear to be typical elements of hyena impact and characterize predator occupation. However, it is difficult to 
attribute these slightly reduced bone morphologies (sub-complete bones, cylinders) to the hyena alone. Indeed, Binford (1981), Haynes (1980) and Fosse et al. (2011) illustrate bone morphotypes produced by the wolf that correspond perfectly to descriptions of hyena bone morphotypes. Moreover, the observation of fragmentation rates at Fouvent somewhat modifies the existing model. Diaphyseal splinters are widely represented and characterize bone reduction. The same observation applies to other dens, such as Bois-Roche (Villa et al. 2004) and Conives (Fourvel 2012). Kuhn (2011) observes just as high a long bone fragmentation rate for present-day striped hyenas in Jordan ( $75 \%$ of diaphyseal splinters). This high fragmentation probably denotes the need to over-consume bone as a result of an insufficient biomass for hyenas' requirements. The variability of the fragmentation rate recorded at different sites probably results from different ecological and environmental factors. The distinction between cold phase sites (Fouvent, Bois-Roche and Conives; high fragmentation) and sites from temperate phases (Lunel-Viel 1; low fragmentation) may be a consequence of food stress. Climatic and environmental constraints during cold phases induce higher energy expenditure and therefore lead to a more intensive exploitation of bone material in order to compensate for this expenditure. Conversely, during temperate phases, in spite of a lower biomass (in part due to more closed environments), lower energy expenditure as a result of more favourable climatic and environmental conditions does not lead to the extreme exploitation of bone material by the predator.

iv. Up until now, only the presence of consumption marks and sometimes their intensity (in terms of frequency) have been mentioned regularly. Their association with the aforementioned criteria contributed to characterizing the den (Fosse 1994). 


\section{6 - Conclusion} methods) or taphonomic bias (weathering). It is thus essential to use actualistic data to understand these variations. The comparative analysis of bone material and ecoethological knowledge reveals disparities in currently used characterization grids. As for other social carnivores, hyena predation modes adapt to environmental constraints. Food stress and increased energy expenditure caused by harsh climatic conditions can force hyenas to modify their strategies and exploit bone elements more intensively, with increased reduction. The size of Pleistocene packs, the duration of den occupation or occupation seasonality are still difficult hypotheses to prove but which can have a real impact on hyena behaviour. Moreover, hyenas tend to accentuate their accumulative behaviour in order to limit interactions with other predators. Ultimately, only the analysis of a Pleistocene den can define or contribute to establishing characterization criteria. The comparison and use of actualism also contribute to defining taphonomic variations and the palaeo-eco-ethologic interpretation of these variations. The comparison of data from the Fouvent analysis with other Pleistocene and modern assemblages is part of this comparative taphonomy perspective.

\section{BIBLIOGRAPHY}

BEARDER S.K. 1977 - Feeding habits of spotted hyaenas in a woodland habitat. East Africa Wildlife Journal, 15, p. 263-280.

BEAUVAL C. et MORIN E. 2010 - Les repaires d'hyènes du Lussacois (Lussac-les-Châteaux, Vienne, France). Apport des sites des Plumettes et des Rochers-de- Villeneuve. In : J. Buisson-Catil \& J. Primault (eds) Préhistoire entre Vienne et Charente. Hommes et sociétés du Paléolithique, p. 175-189. BINFORD L.R. 1981 - Bones : Ancient men and modern myths. Academic Press, New York, 319 p. BLUMENSCHINE R. J. 1988 - An Experimental Model of the Timing of Hominid and Carnivore Influence on Archaeological Bone Assemblages. Journal of Archaeological Science, 15, p. 483-502. 
BOUILLEROT A. 1881 - L'Homme des carvernes et les animaux Quaternaires autour de la Montagne de Marey (Haute-Saône) - Grotte de Fouvent. Bulletin de la Société d'Agriculture, Sciences et Arts du Département de la Haute-Saône, 3e série, n 11, p. 50-66.

BRAIN C.K. 1981 - The hunters or the hunted? An introduction to African cave taphonomy, University Press, Chicago, 365p.

BRUGAL J.-P. 2010 - Carnivores pléistocènes (Hyénidés, Canidés, Félidés) dans les grottes du Portugal. Actas de la 1a Reunion de cientificos sobre cubiles de hiena (y otros grandes carnivoros) en los yacimientos arqueologicos de la Peninsula Ibérica, Zona arqueológica, 13, p. 92-106.

BRUGAL J.-P., FOSSE P. \& GUADELLI J.-L. 1997 - Comparative study of bone assemblages made by recent and pleistocene hyenids. In : L. A. Hannus, L. Rossum \& R. P. Winham (eds) Proceedings of the 1993 bone modification conference, Hot Springs, South Dakota, p. 158-187.

BUCKLAND W. 1822 - Account of an Assemblage of Fossil Teeth and Bones of Elephant, Rhinoceros, Hippopotamus, Bear, Tiger, and Hyaena, and Sixteen Other Animals; Discovered in a Cave at Kirkdale, Yorkshire, in the Year 1821: With a Comparative View of Five Similar Caverns in Various Parts of England, and Others on the Continent. Philosophical Transactions of the Royal Society of London, 112, p. 171-236.

BUNN H.T. 1983 - Comparative analysis of modern bone assemblages from a San hunter-gathere camp in the Kalahari Desert, Botswana, and from a spotted hyaena den near Nairobi, Kenya. In: J. Clutton-Brock \& C. Grigson (Eds.), Animals and Archaeology : 1. Hunters and their Prey, p. 143-148.

CARTAILHAC E. 1881 - Préhistorique dans les Pyrénées de la Haute-Garonne, p. 730-738. In : A. Leymerie (ed) Descritpion géologique et paléontologique des Pyrénées de la Haute-Garonne Ed. Privat, Toulouse, p. 730-738.

CRUZ-URIBE K. 1991 - Distinguishing Hyena from Hominid Bone Accumulations. Journal of Field Archaeology, 18(4), p. 467-486.

CUVIER G. 1812 - Recherches sur les Ossements Fossiles de Quadrupèdes, Deterville, Paris, 682 p.

CUVIER G. 1825 - Recherches sur les ossements fossiles,Paris.

DEAUJARD C. 2008 - Exploitation du milieu animal par les Néanderthaliens dans le sud-est de la France. Lyon : Université Lumière, Archéorient - Environnements et Sociétés de l'Orient ancien, Lyon 2: $510 \mathrm{p}$.

DETREY J. 1992 - L'Abri Cuvier, Fouvent-le-Bas (Haute- Saône). Rapport 1992.

DISCAMPS E. 2011 - Hommes et hyènes face aux recompositions des communautés d'Ongulés (MIS 5-3) : Eléments pour un cadre paléoécologique des sociétés Paléolithique moyen te supérieur ancien d'Europe de l'Ouest. Bordeaux : Université Bordeaux 1, Ecole Doctorale Sciences et Environnements, Bordeaux $1: 438 \mathrm{p}$.

DOMINGUEZ-RODRIGO M. \& PICKERING T. R. 2010 - A Multivariate Approach for Discriminating Bone Accumulation Created by Spotted Hyenas and Leopards: Harnessing Actualistic Data from East and Southern Africa. Journal of Taphonomy, 8(2-3), p. 155-179.

FERNANDEZ P., GUADELLI J.-L. \& FOSSE P. 2006 - Applying dynamics and comparing life tables for Pleistocene Equidae in anthropic (Bau de l'Aubesier, Combe-Grenal) and carnivore (Fouvent) contexts with modern feral horse populations (Akagera, Pryor Mountain). Journal of Archaeological Science, 33(2), p. 176-184.

FOSSE P. 1994 - Taphonomie Paléolithique : Les grands mammiferes de Soleilhac (Haute-Loire) et de Lunel-Viel 1 (Hérault). Aix-Marseille : Université de Provence, Laboratoire d'Anthropologie et de 
Préhistoire des Pays de la Méditerranée Occidentale. Laboratoire de Géologie du Quaternaire, Aix-Marseille I : 318 p.

FOSSE P. 1995 - Le rôle de l'hyène dans la formation des assemblages osseux : 150 ans de controverses, L'apport des anciens textes de préhistoire et de paléontologie du Quaternaire aux études taphonomiques actuelles. Paleo, 7 : p. 49-84.

FOSSE P. 1997 - Variabilité des assemblages osseux créés par l'hyène des cavernes. Paleo, 9, p. $15-54$.

FOSSE P., AVERY G., SELVA N., SMIETANA W., OKARMA H., WAJRAK A., FOURVEL J.-B. et MADELAINE S. 2011 - Taphonomie comparée des os longs d'ongulés dévorés par les grands prédateurs modernes d'Europe et d'Afrique (C. lupus, P. brunnea). In: J.-P. Brugal, A. Gardeisen \& A. Zucker (eds) Prédateur dans tous leurs états. Evolution, Biodiversité, Interactions, Mythes, Symboles. XXXIe rencontres internationales d'archéologie et d'histoire d'Antibes. APDCA, Antibes, p. 127-156.

FOURVEL J.-B. 2010 - Identifying the Predator: A Cautionary Example. Journal of Taphonomy, 8(4), p. 335-336.

FOURVEL J.-B. 2012 - Hyénidés modernes et fossiles d'Europe et d'Afrique : taphonomie comparée de leur assemblages osseux. Toulouse : Université de Toulouse- Le Mirail, Thèse de doctorat, Toulouse 2 : $615 \mathrm{p}$.

FOURVEL J.-B. \& MWEBI O. 2011 - Hyenas' level of dependence on livestock in pastoralist areas in the Republic of Djibouti and Kenya: relation between prey availability and bone consumption sequence. In: J.-P. Brugal, A. Gardeisen \& A. Zucker (eds) Prédateur dans tous leurs états. Evolution, Biodiversité, Interactions, Mythes, Symboles. XXXIe rencontres internationales d'archéologie et d'histoire d'Antibes. APDCA, Antibes, p. 157-176.

GERVAIS P. 1870 - Restes fossiles du Glouton receuillis en France. Matériaux pour l'Histoire Primitive et Naturelle de l'Homme et de l'étude du sol, de la faune et de la flore qui s'y rattachent, sixième année, 2è série, p. 284-286.

GUADELLI J.-L. 1987 - Contribution à l'étude des zoocénoses préhistoriques en Aquitaine (Würm ancien et Interstade würmien). Bordeaux : Institut du Quaternaire Université de Bordeaux 1, Talence, 3 Tomes : $1247 \mathrm{p}$.

HAYNES G. 1980 - Evidence of Carnivore Gnawing on Pleistocene and Recent Mammalian Bones. Paleobiology, 6(3), p. 341-351.

ILANY G. 1975 - Hyenas in Israel. Israel - Land and Nature, Oct. 1975, p. 10-18.

KLEIN R.G. \& CRUZ-URIBE K. 1983 - The Computation of Ungulate Age (Mortality) Profiles from Dental Crown Heights. Paleobiology, 9(1), p. 70-78.

KRUUK H. 1972 - The Spotted Hyena : A Study of Predation and Social Behavior. Wildlife Behavior and Ecology, $335 \mathrm{p}$.

KUHN B. 2011 - Hyaenids: Taphonomy and Implications for the Palaeoenvironment. Cambridge Scholars Publishing, $220 \mathrm{p}$.

KUHN B.F., BERGER L.R. \& SKINNER J.D. 2008 - Examining Criteria for Identifying and Differentiating Fossil Faunal Assemblages Accumulated by Hyenas and Hominins using Extant Hyenid Accumulations. International Journal of Osteoarchaeology, p. 1-21.

LOVIS F. 1968 - Révision de la Faune Fossile de la Grotte de Fouvent le Bas (Haute-Sôane). Besançon : Université de Besançon, Faculté des Sciences : 76 p. 
MAGNIEZ P. 2010 - Etude paléontologique des Artiodactyles de la grotte Tournal (Bize-Minervois, Aude, France). Etude taphonomique, archéozoologique et paléoécologique des grands Mammifères dans leur cadre biostratigraphique et paléoenvironnemental. Perpignan : Université de Perpignan Via Domitia : 916 p.

MAGUIRE J. M., PEMBERTON D. \& COLLET M.H. 1980 - The Makapansgat Limeworks Grey Breccia: Hominids, hyaenas, hystricids or hillwash? Palaeontologia Africana, 23, p. 75-98.

MICHEL P. 2005 - Un repaire würmien d'hyènes des cavernes: La Grotte d'Unikoté (Iholdy, Pyrénées-Atlantique, France). Museo de Altamira. Monografias, 20 (131-150).

MILLS M.G.L. 1982 - Notes on age determination, growth and measurements of brown hyaenas Hyaena brunnea from the Kalahari Gemsbok National Park. Koedoe, 25, p. 55-61.

MILLS M.G.L. 1990 - Kalahari hyaenas: the comparative behivioural ecology of two species. Chapman \& Hall, London : $304 \mathrm{p}$.

NODOT L. 1858-1859 - Une Visite à la grotte de Fouvent (Haute-Saône) : ossements fossiles et débris de l'industrie humaine. Mémoire de l'Académie Impériale des Sciences, Arts et Belles-Lettres de Dijon, Tome VII, Deuxième série, p. 113-143.

PHILIPPE M. et FOSSE P. 2003 - La faune de la grotte Chauvet (Vallon-Pont-d'Arc) : présentation préliminaire paléontologique et taphonomique. Paleo, 15, p. 123-140.

PICKERING T.R. 2002 - Reconsideration of Criteria for Differentiating Faunal Assemblages Accumulated by Hyenas and Hominids. International Journal of Osteoarchaeology, 12, p. 127-141.

RICHARDSON P.R.K. 1980 - Carnivore Damage to Antelope Bones and its Archaeological Implications. Palaeontologica Africana, 23, p. 109-125.

SALNICKI J., TEICHMANN M., WILSON V.J. \& MURINDAGOMO F. 2001 - Spotted hyaenas Crocuta crocuta prey on new-born elephant calves in Hwange National Park Zimbabwe. Koedoe, 44 (2), p. 79-83.

STEELE T.E. 2005 - ComparingMethods for Analysing Mortality Profiles in Zooarchaeological and Palaeontological Samples. International Journal of Osteoarchaeology, 15, p. 404-420.

STINER M.C. 1990 - The Use of Mortality Patterns in Archaeological Studies of Hominid Predatory Adaptations. Journal of Anthropological Archaeology, 9, p. 305-351.

STINER M.C. 1991 - The Faunal Remains From Grotta Guattari: A Taphonomic Perspective. Current Anthropology, 32 (2), p. 103-117.

STINER M.C. 1994 - Honor among Thieves: A Zooarchaeological Study of Neandertal Ecology. Princeton University Press : 447p.

SUTCLIFFE A.J. 1970 - Spotted Hyaena: Crusher, Gnawer, Digester and Collector of Bones. Nature, 227, p. 1110-1113.

THENIUS E. 1961 - Hyänenfraßspuren aus dem Pleistozän von Kärnten. Ein Beitrag zur Frage der sog. « osteodontokeratischen Kultur » des Australopithecinen (Hominidae). Carinthia II, Naturwissenschaftlicher Verein fuer Kaernten, p. 88-101.

THIRRIA E. 1828 - Notice sur les grottes d'Echenoz et de Fouvent, sises dans le département de la Haute-Saône, et sur les ossemens fossiles qu'elles renferment. Comptes Rendus des séances de l'Académie des Sciences, p. 1-22.

THIRRIA E. 1833 - Statistique Minéralogique et Géologique du Département de la Haute-Saône. Besançon, $465 \mathrm{p}$. 
VILLA P., CASTEL J.-C., BEAUVAL C., BOURDILLAT V. \& GOLDBERG P. 2004 - Human and carnivore sites in the European Middle and Upper Paleolithic: Similarities and differences in bone modification and fragmentation. Revue de Paléobiologie, 23 (2), p. 705-730.

VILLA P. \& MAHIEU E. 1991 - Breakage patterns of human long bones. Journal of Human Evolution, 21, p. 27-48.

ZAPFE H. 1939 - Die Lebensspuren der eiszeitlichen Höhlenhyänen. Die urgeschichtliche Bedeutung der Lebensspuren knochenfressender Raubtiere. Forsch. u. Fortschr., 15, p. 269-270.

\section{ABSTRACTS}

The palaeontological site of Fouvent (Fouvent-le-Bas, Haute-Saône, France) is a fissure-filling bone accumulation known from the beginning of the XIXth century. This assemblage is at the origin of palaeontological (description of fossil hyena by Cuvier, first record of French wolverine) and taphonomical advances (first carnivore den characterization). This paper presents the analysis of 14977 bone remains from both the historical collection (1842) and recent excavations (between 1989 and 1992). A faunal list of 19 mammalian species has been identified: 11 carnivore species (Crocuta crocuta spelaea, Panthera (Leo) spelaea, Ursus spelaeus, Canis lupus, Vulpes vulpes, cf. Alopex, Gulo gulo, Meles meles, Martes sp., Mustela eversmanii, Mustela sp.) and 8 large ungulate species (Mammuthus primigenius, Coelodonta antiquitatis, Megaloceros giganteus, Cervus elaphus, Rangifer tarandus, Equus germanicus, Bos primigenius and/or Bison priscus). The analysis of cave hyenas from Fouvent allows us to precise characteristics of an OIS3 population and to discuss population structure. The study of ungulate populations allows us to describe prey diversity (in terms of species and individual age). Prey skeletal part distribution, bone fragmentation, consumption morphotypes and tooth marks are observed to point out predator-prey interactions. The detailed analysis of taphonomical aspects of Fouvent bone accumulation allows also to discuss and to give criteria about hyena den characterization grids.

Le gisement paléontologique de Fouvent (Fouvent-le-Bas, Haute-Saône, France) est une accumulation osseuse karstique connue depuis le début du XIXe siècle. Ce site est à l'origine de nombreuses avancées paléontologiques (reconnaissance de l'hyène fossile par Cuvier, première mention du glouton en France) et taphonomique (caractérisation du repaire de carnivore). Le présent article porte sur l'analyse de 14977 restes osseux issus à la fois de la collection historique (fouilles de 1842) et des fouilles récentes (1989-1992). Une liste faunique de 19 taxons de grands mammifères a été établie : 11 carnivores (Crocuta crocuta spelaea, Panthera (Leo) spelaea, Ursus spelaeus, Canis lupus, Vulpes vulpes, cf. Alopex, Gulo gulo, Meles meles, Martes sp., Mustela eversmanii, Mustela sp.) et 8 ongulés (Mammuthus primigenius, Coelodonta antiquitatis, Megaloceros giganteus, Cervus elaphus, Rangifer tarandus, Equus germanicus, Bos primigenius et/ou Bison priscus). L'étude des hyènes des cavernes permet de préciser les caractères d'une population du stade isotopique 3 et de discuter de sa composition. Quant au spectre d'ongulés, son identification permet de préciser la diversité des proies de l'hyène (en termes d'espèces et d'âges individuels). Les interactions entre le prédateur et ses proies sont caractérisées grâce à l'étude de la distribution squelettique, de la fragmentation osseuse, des morphologies des restes consommés et des traces de dents. L'examen détaillé de l'ensemble des éléments taphonomiques de l'accumulation osseuse de Fouvent permet de discuter et de préciser la spécificité d'un repaire d'hyènes pléistocène. 
INDEX

Keywords: Fouvent, Hyena den, OIS3, Bone accumulation, Taphonomy, Palaeoecology

Mots-clés: Fouvent, repaire d'hyènes, accumulation osseuse, OIS3, taphonomie, paléoécologie

\section{AUTHORS}

JEAN-BAPTISTE FOURVEL

Université Toulouse Le Mirail, UMR5608-TRACES, FR-31000 Toulouse - jbfourvel@yahoo.com PHILIPPE FOSSE

Université Toulouse Le Mirail, UMR5608-TRACES, FR-31000 Toulouse - fosse@univ-tlse2.fr

\section{PHILIPPE FERNANDEZ}

Aix-Marseille Université, CNRS, MCC, LAMPEA UMR 7269, FR-13617Aix-en-Provence philippe.fernandez@univ-amu.fr

\section{PIERRE-OLIVIER ANTOINE}

Institut des Sciences de l'Évolution, UMR-CNRS 5554, CC064, Université Montpellier 2, Place

Eugène Bataillon, FR-34095 Montpellier - pierre-olivier.antoine@univ-montp2.fr 